(c) American Dairy Science Association, 2006.

\title{
Genetic Analysis of Persistency in the Israeli Holstein Population by the Multitrait Animal Model
}

\author{
J. I. Weller, ${ }^{\star 1}$ E. Ezra,† and G. Leitner $¥$ \\ *Institute of Animal Sciences, ARO, The Volcani Center, Bet Dagan 50250, Israel \\ †Israel Cattle Breeders Association, Caesaria Industrial Park, Caesaria 38900, Israel \\ ¥Kimron Veterinary Institute, Bet Dagan 50250, Israel
}

\section{ABSTRACT}

Persistency was defined as the predicted milk production $180 \mathrm{~d}$ after peak divided by peak production (in $\%)$. Heritability of persistency in a multitrait analysis including parities 1 through 5 increased from 0.16 to 0.27 from first through third parity, and then declined through fifth parity. Genetic correlations for persistency between consecutive parities were all $>0.8$. Firstparity genetic correlations of the traits included in the Israeli selection index with persistency were all $<0.1$, except for fertility and herdlife, which were 0.20 and 0.25 ; whereas second-parity genetic correlations of persistency with the 3 milk production traits were all $>0.34$, and the genetic correlation with fertility was only 0.10 . The genetic correlation between second-parity persistency and herdlife was 0.58 . Persistency in the Israeli Holstein population was analyzed by the multitrait animal model. The genetic trend since 1985 for the multiparity index was $0.22 \%$ persistency/yr, even though there was no direct selection on persistency.

Key words: persistency, multitrait animal model, Israeli Holstein, genetic evaluation

\section{INTRODUCTION}

Persistency of milk production (PER) is generally defined relative to the distribution of yield along the lactation. The more even the distribution, the greater the PER. Numerous studies have analyzed milk yield PER (reviewed by Gengler, 1996). Higher PER is considered advantageous because of the lower ratio between peak and mean production. This allows for better use of cheap roughage (Solkner and Fuchs, 1987), reduction of stress at peak production (Zimmermann and Sommer, 1973), and increased profit. For individual lactations of $305 \mathrm{~d}$, PER affected only feed costs, but for other lactation lengths, PER had a greater impact on

Received August 16, 2005.

Accepted November 20, 2005.

${ }^{1}$ Corresponding author: weller@agri.huji.ac.il milk returns per lactation than on feed costs. Under an optimized insemination and culling strategy, the economic value of PER was Can\$13.6 per phenotypic standard deviation, but increased with level of PER (Dekkers et al., 1998).

Ferris et al. (1985) first considered the possibility of modifying the lactation curve by selection. They concluded that selection on PER would decrease gain in milk production. Grossman et al. (1986) concluded that the possibility of changing the shape of the lactation curve is small. More recent studies have been more optimistic as to the possibility of joint selection for milk yield and PER (Togashi and Lin, 2003, 2004a,b).

Many studies have shown an antagonistic relationship between milk production, especially at peak, and cow fertility (reviewed by Muir et al., 2004). Bar-Anan and Wiggans (1985) first demonstrated a positive genetic correlation between PER and female fertility. Muir et al. (2004) suggested that selection for increased PER might increase total yields without increasing disease occurrence or reproductive failure. They found a genetic correlation of 0.32 between first-parity PER and 56-d nonreturn rate. Jakobsen et al. (2003) also found a weak negative correlation between disease liability and PER; that is, lower PER was associated with greater disease liability.

Many different criteria have been used to estimate PER. Swalve and Gengler (1999) classified the criteria into 4 groups, but none are optimal or generally accepted. Recently, random regression models have also been applied (Jamrozik et al., 1998; Kistemaker, 2003; de Roos et al., 2004). Random regression models allow for better adjustment for environmental effects, for the possibility to include lactations with only a few records, and for differently shaped lactation curves for each animal. Muir et al. (2004) proposed the regression of the lactation curve after peak, as derived from the Wilmink lactation function (Wilmink, 1987). This method has the advantage that all test days are utilized to estimate PER, and therefore should be relatively stable, as opposed to PER measures that are based on only 1 or 2 test-day values (e.g., Bar-Anan and Wiggans, 1985). It has the disadvantages that it is necessary to compute 
3 regression coefficients from a small number of data points, and assumes that the time of peak production is known. Muir et al. (2004) did not adjust their measure of PER for differences in peak production.

All studies that have considered multiple parities agree that PER decreases with an increase in parity (Gengler, 1996). Phenotypic correlations among parities, although positive, are generally low (Gengler, 1996). Several studies have estimated genetic correlations among parities for PER, and all estimates were positive. Correlations between first- and second-parity PER ranged from 0.37 to 0.77 , and correlations between second- and third-parity PER ranged from 0.60 to 0.94 (Jamrozik et al., 1998; van der Linde et al., 2000; Gengler et al., 2001; de Roos et al., 2004).

Weller and Ezra (2004) recently completed a genetic analysis of Israeli Holstein dairy cattle population by the multitrait animal model (Da and Grossman, 1991) for 5 traits: milk, fat, and protein production, SCS, and female fertility. Their analysis included parities up to fifth, and the different parities were considered correlated traits with known genetic and environmental covariance matrices.

The objectives of this study were as follows: a) to estimate genetic and environmental correlations for PER among parities 1 through 5 ; b) to estimate genetic and environmental correlations among PER, milk production, fertility, and other economic traits in first and second parity; c) to estimate phenotypic and genetic trends for PER in the Israeli Holstein population; and d) to determine the expected change in PER due to selection according to the Israeli selection index.

\section{MATERIALS AND METHODS}

\section{Data}

The analysis was based on 18,058,130 test-day milk production records of first through fifth parity milkrecorded Israel Holsteins calving between January 1985 and September 2004. Daily milk production records $<10 \mathrm{~kg}$ or $>90 \mathrm{~kg}$ were deleted, leaving 17,931,188 valid test-day records. Records $<10 \mathrm{~kg}$ were deleted because these most likely represent sick cows or recording mistakes. Test-day records $<4 \mathrm{~d}$ or $>400 \mathrm{~d}$ after calving, and records of cows with unknown sire were also deleted. Mean lactation curves for each parity were computed based on means of 5 -d classes.

\section{Computation of PER}

Persistency of milk production, defined as estimated milk production $180 \mathrm{~d}$ after peak divided by estimated peak production in percent, was computed as follows:

$$
\begin{gathered}
\text { PER } 1=100 \% \times \operatorname{PROD}(270) / \operatorname{PROD}(90) \\
\text { PER2 }+=100 \% \times \operatorname{PROD}(225) / \operatorname{PROD}(45)
\end{gathered}
$$

where PER1 = first-parity PER, PER2+ = PER for parities 2 through $5, \mathrm{PROD}=$ production, and $\mathrm{PROD}(\mathrm{DIM})=$ $\mathrm{a}+\mathrm{b} \times \mathrm{DIM}$, where $\mathrm{a}$ and $\mathrm{b}$ are the $\mathrm{y}$-intercept and regression of milk production on DIM after peak, respectively. Peak milk production for first and later parities, $\operatorname{PROD}(90)$ and $\operatorname{PROD}(45)$, were assumed to occur at 90 and 45 DIM. The values for a and $b$ were computed for each lactation based on the first 10 test-day records after 90 DIM for first-parity cows, and after 45 DIM for later parity cows. Persistency of milk production was computed for lactations of cows with freshening dates at least 10 mo prior to the date of analysis; and at least 6 valid test-day records after peak, provided that these records spanned at least $120 \mathrm{~d}$, and that the first record was $\leq 135$ DIM for first-parity cows and $\leq 90$ DIM for later parity cows.

The 2 time points chosen for the calculation of PER were $180 \mathrm{~d}$ apart. Other studies compared production at 60 and 280 DIM, which are $220 \mathrm{~d}$ apart (e.g., Gengler et al., 2001), but did not account for the fact that the peak is later for first parity. Requiring $220 \mathrm{~d}$ after peak for first lactation (i.e., 310 DIM) would have resulted in deleting many valid lactation records or extrapolating production beyond the actual lactation end.

\section{Analysis Models}

The REML multitrait animal model variance components were computed for PER, corrected for the effects of days open (DO), parity, and calving month by the MTC program (multitrait REML estimation of variance components program by canonical transformation, with support for multiple random effects; I. Misztal, University of Georgia, Athens, GA, personal communication). These factors were not included in the REML analyses because the program required that the same analysis model be applied for all traits, and unadjusted records were not available for the other traits. Furthermore, the variance components derived from the multiparity REML analysis were used for the genetic analysis of the complete population, and this model was also based on PER records adjusted for DO and calving month.

The effects of DO, parity, and calving month on PER were determined by a fixed linear model analysis. Only lactations with freshening dates since 1994, and DO> 0 and $<200$ were included in these analyses. The data set was limited to lactations since 1994 because of software limitations. Records with $>200$ DO were deleted because a large fraction of these might represent abortions, incorrect recording of the effective insemination date, or cows with diseases of the reproductive system. 
Table 1. Number of levels for the REML and multitrait animal model analyses

\begin{tabular}{|c|c|c|c|c|}
\hline Type of analysis & Parities & Traits & Factor & Number of levels \\
\hline \multirow[t]{5}{*}{ Fixed model } & \multirow[t]{5}{*}{1 to 5} & \multirow[t]{5}{*}{ Persistency } & $(\text { Days open })^{0.5}$ & Regression \\
\hline & & & Days open & Regression \\
\hline & & & Parity & 5 \\
\hline & & & Parity $\times$ freshening month & 60 \\
\hline & & & Number of records & 543,384 \\
\hline \multirow[t]{4}{*}{ REML1 } & \multirow[t]{4}{*}{1 to 5} & \multirow[t]{4}{*}{ Persistency } & Groups & 2 \\
\hline & & & Herd-year-seasons & 18,687 \\
\hline & & & Cows with records & 62,510 \\
\hline & & & Total animals & 121,223 \\
\hline \multirow[t]{4}{*}{ REML2 } & \multirow[t]{4}{*}{1} & \multirow{4}{*}{$\begin{array}{l}\text { Persistency, milk, } \\
\text { fat, protein, SCS, } \\
\text { fertility, herdlife }\end{array}$} & Groups & 2 \\
\hline & & & Herd-year-seasons & 9,635 \\
\hline & & & Cows with records & 89,046 \\
\hline & & & Total animals & 186,720 \\
\hline \multirow{4}{*}{ REML3 } & \multirow[t]{4}{*}{2} & \multirow{4}{*}{$\begin{array}{l}\text { Persistency, milk, } \\
\text { fat, protein, SCS, } \\
\text { fertility, herdlife }\end{array}$} & Groups & 2 \\
\hline & & & Herd-year-seasons & 9,122 \\
\hline & & & Cows with records & 67,409 \\
\hline & & & Total animals & 148,186 \\
\hline \multirow[t]{4}{*}{ REML4 } & \multirow[t]{4}{*}{1 to 2} & \multirow{4}{*}{$\begin{array}{l}\text { Persistency, milk, } \\
\text { fertility, herdlife }\end{array}$} & Groups & 2 \\
\hline & & & Herd-year-seasons & 7,145 \\
\hline & & & Cows with records & 68,777 \\
\hline & & & Total animals & 152,168 \\
\hline \multirow[t]{5}{*}{ Animal model } & \multirow[t]{5}{*}{1 to 5} & \multirow[t]{5}{*}{ Persistency } & Groups & 60 \\
\hline & & & Herd-year-seasons & 59,167 \\
\hline & & & Parity $\times$ time period & 10 \\
\hline & & & Cows with records & 484,721 \\
\hline & & & Total animals & 579,030 \\
\hline
\end{tabular}

${ }^{1}$ There was only a single herdlife record per animal.

All parities were analyzed jointly, but the effects for DO and calving month were computed separately for each parity. In the preliminary analyses, square root, linear, and quadratic effects of DO were included in the models. The number of records, the effects, and the number of level of effects included in the final analyses are given in Table 1. The base for calculation of all effects was fifth-parity cows calving in April with zero DO.

The MTC program can include individuals without records, but requires that individuals with records should have records for all traits included in the analysis. All known parents and grandparents of cows with records were included in the REML and multitrait animal model analyses. Animals with unknown sires were not included in the analyses. All models included a fixed effect of herd-year-season and a group effect for individuals with unknown parents, in addition to the random genetic animal effect. Two seasons were defined for each herd-year, from April through September, and from October through March. Two genetic groups were defined for individuals with unknown parents: one group for animals with both parents unknown, and a second group for animals with known sire, but unknown dam. For each analysis, 100 iterations were run.

Variance components were computed as follows: 1) among PER for the 5 parities, REML1; 2) among firstparity PER and first-parity values for the 6 traits included in the Israeli breeding index, PD04 (Ezra and
Weller, 2005), REML2; 3) among second-parity PER and second-parity values for these 6 traits, REML3; and 4) among herdlife and first- and second-parity PER, milk, and fertility, REML4. The traits included in PD04 are also listed in Table 1. The herd-year-season effect was defined relative to first parity for all analyses, except for the REML2 analysis, which included only second-parity records. There was only a single herdlife record for each animal. Thus, the same values were used for this trait in the REML2, REML3, and REML4 analyses.

Milk, fat, and protein yield to $305 \mathrm{~d}$ were computed as described by Ezra et al. (1987), and adjusted for DO, calving age and month, and parity using multiplicative factors. Female fertility was computed as the inverse of the number of inseminations to conception (in \%; Weller and Ezra, 1997). Herdlife was computed as the number of days from first calving to culling. Cows that were not inseminated did not have records for fertility; cows that were not culled did have herdlife records, as described by Settar and Weller (1999).

The software used imposed limitations on the size of the data sets and the number of traits that could be included in each analysis. The REML1 analysis included all cows with valid PER records on all 5 parities and first-parity freshening dates since 1985, and the REML2 and REML3 analyses included all cows with valid records for all 7 traits for the respective parity and freshening dates between 1995 and 1998. The REML4 


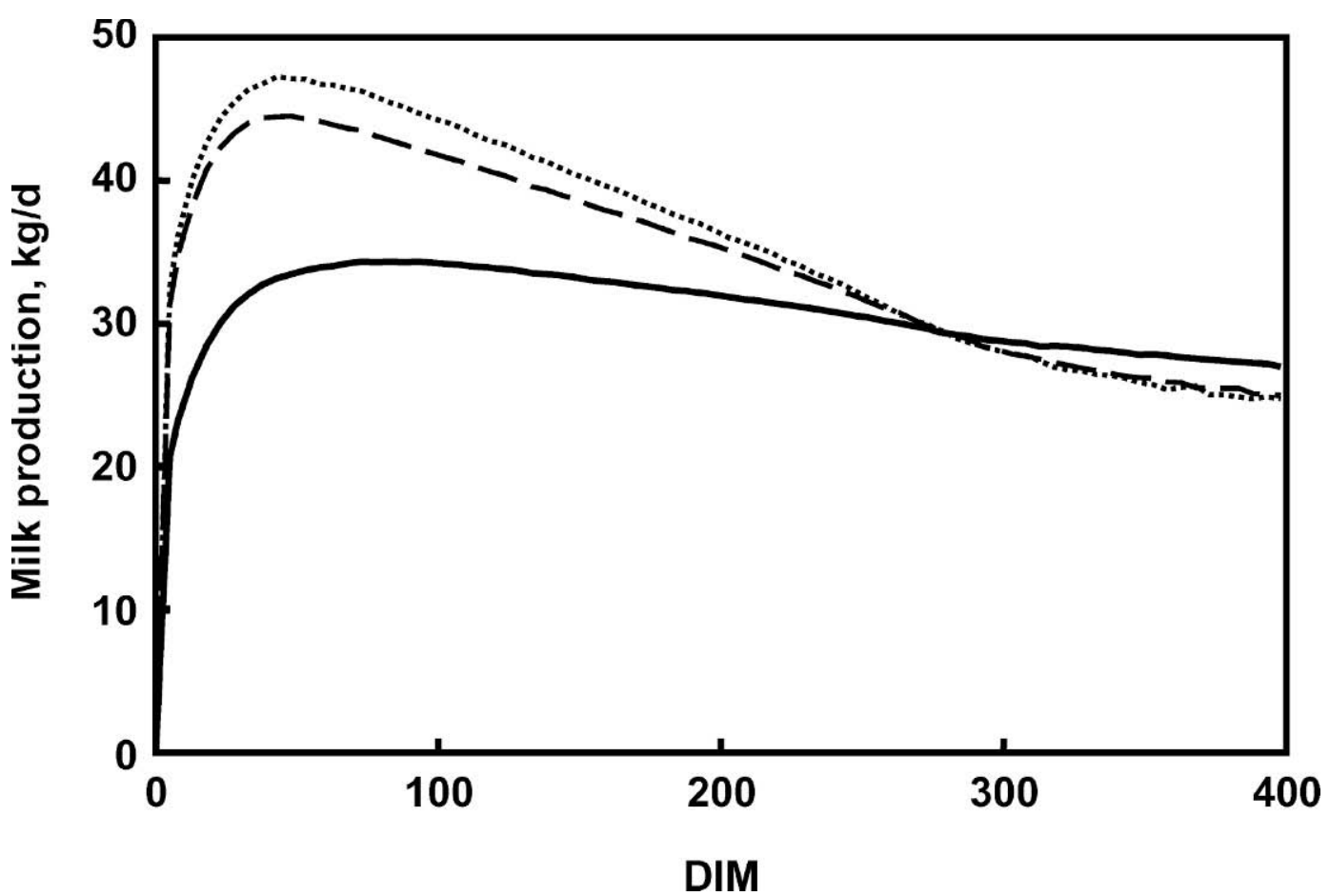

Figure 1. Dairy milk production as a function of DIM. Solid line = first parity; dashed line = second parity; and dotted line = third parity .

analysis included all cows with valid records for the traits included in the analysis for both parities, and second-parity freshening dates between 1995 and 1998 . The number of records, the effects, and the number of level of effects included in these analyses are also given in Table 1.

Genetic evaluations were computed for PER for the entire milk-recorded population by the multitrait animal model as described previously for milk production traits (Weller and Ezra, 2004) using the variance components obtained from the REML1 analysis. The analysis model was:

$$
\mathrm{Y}_{\mathrm{ijkl}}=\mathrm{H}_{\mathrm{i}}+\mathrm{G}_{\mathrm{jl}}+\mathrm{A}_{\mathrm{kl}}+\mathrm{P}_{\mathrm{m}}+\mathrm{e}_{\mathrm{ijklm}}
$$

where $\mathrm{Y}_{\mathrm{ijkl}}=$ the adjusted PER record for parity $\mathrm{l}$ of cow $\mathrm{k}$ from herd-year-season $\mathrm{i}, \mathrm{H}_{\mathrm{i}}=$ the effect of herdyear-season $i, G_{j l}=$ the effect of genetic group $j$ for parity $\mathrm{l}, \mathrm{A}_{\mathrm{kl}}=$ the additive genetic effect of cow $\mathrm{k}$ for parity $\mathrm{l}$, $\mathrm{P}_{\mathrm{m}}=$ the parity-by-time period effect for parity-by-time period level $\mathrm{m}$, and $\mathrm{e}_{\mathrm{ijkl}} \mathrm{m}=$ random residual.

All cows with valid first-parity PER records, and firstparity freshening dates since 1985 were included in the analysis. Parents and grandparents of these cows were also included as described previously (Weller and Ezra, 2004). For individuals with unknown parents, 60 genetic groups were defined based on birth dates and on which parents were missing. Separate herd-year- seasons were defined for first and later parity cows. This model differed from the model for the REML analyses in that a parity-by-time period effect was also included. Therefore, although records were precorrected for DO and calving month, precorrection for parity effect was unnecessary. Two "time-period" levels were defined as cows with first-parity freshening dates through 1994, and cows with first-parity freshening dates after 1994. The number of records, the effects, and the number of levels of effects included in this analysis are also given in Table 1.

In the multiparity animal model, genetic evaluations were computed for each animal for each parity. These values were combined into a multiparity index (BVT), as follows:

$$
\begin{aligned}
\mathrm{BVT}=\left(\mathrm{BV}_{1}+\right. & 0.73 \mathrm{BV}_{2}+0.51 \mathrm{BV}_{3}+0.34 \mathrm{BV}_{4} \\
& \left.+0.21 \mathrm{BV}_{5}\right) / 2.79
\end{aligned}
$$

where $\mathrm{BV}_{1}$ to $\mathrm{BV}_{5}$ are the individual parity breeding values. The coefficients relative to first parity were derived based on the probability that the cow would produce a record in each parity multiplied by the discounted value of each parity. A 5\% discounting factor was assumed for each additional parity after first (Weller and Ezra, 2004).

Reliabilities were estimated using the algorithm of Misztal and Wiggans (1988), as corrected by Misztal et 
Table 2. Effects of parity, days open (DO), and freshening month by parity for the fixed model analysis ${ }^{1}$

\begin{tabular}{llccccc}
\hline & & \multicolumn{5}{c}{ Parity } \\
\cline { 3 - 6 } Factor & Level & 1 & 2 & 3 & 4 & 5 \\
\hline Parity & & 17.72 & 2.97 & -3.38 & -4.76 & 0.0 \\
DO $^{0.5}$ & Regression & 2.84 & 2.16 & 2.46 & 2.34 & 1.43 \\
DO & Regression & -0.076 & -0.026 & -0.034 & -0.027 & 0.013 \\
Calving month & 1 & -8.24 & -3.23 & -2.19 & -1.46 & -1.44 \\
& 2 & -6.20 & -3.00 & -2.39 & -1.36 & -1.61 \\
& 3 & -3.23 & -1.91 & -1.39 & -0.98 & -1.27 \\
& 4 & 0.0 & 0.0 & 0.0 & 0.0 & 0.0 \\
& 5 & 1.89 & 2.48 & 1.88 & 2.18 & 1.30 \\
& 6 & 1.92 & 4.21 & 3.81 & 3.35 & 3.27 \\
& 7 & 1.51 & 5.16 & 4.31 & 4.49 & 4.39 \\
& 8 & 1.66 & 4.85 & 4.51 & 4.71 & 4.45 \\
& 9 & -0.28 & 3.53 & 3.65 & 4.04 & 4.06 \\
& 10 & -2.53 & 1.29 & 2.17 & 2.74 & 2.75 \\
& 11 & -5.11 & -0.40 & 0.58 & 1.35 & 0.90 \\
& 12 & -8.90 & -2.06 & -1.09 & -0.73 & -0.44 \\
\hline
\end{tabular}

${ }^{1}$ The base for the effect values was fifth-parity cows calving in April with zero days open.

al. (1991). Genetic correlations among sire evaluations for the 7 traits included in the REML2 and REML3 analyses were computed for bulls with reliabilities $>0.75$ for PER, and compared with the genetic correlations as computed by REML2 and REML3. Genetic trends were computed for the individual parity evaluations and the multiparity index as the regression of the genetic evaluations on the cows' birth dates. Similarly, phenotypic trends were computed for each parity as the regression of PER on the cows' birth dates. Multiparity phenotypic trends were not computed because not all cows produced records for all parities.

\section{RESULTS AND DISCUSSION}

Daily milk production as a function of DIM for parities 1, 2, and 3 is plotted in Figure 1. Parities 4 and 5

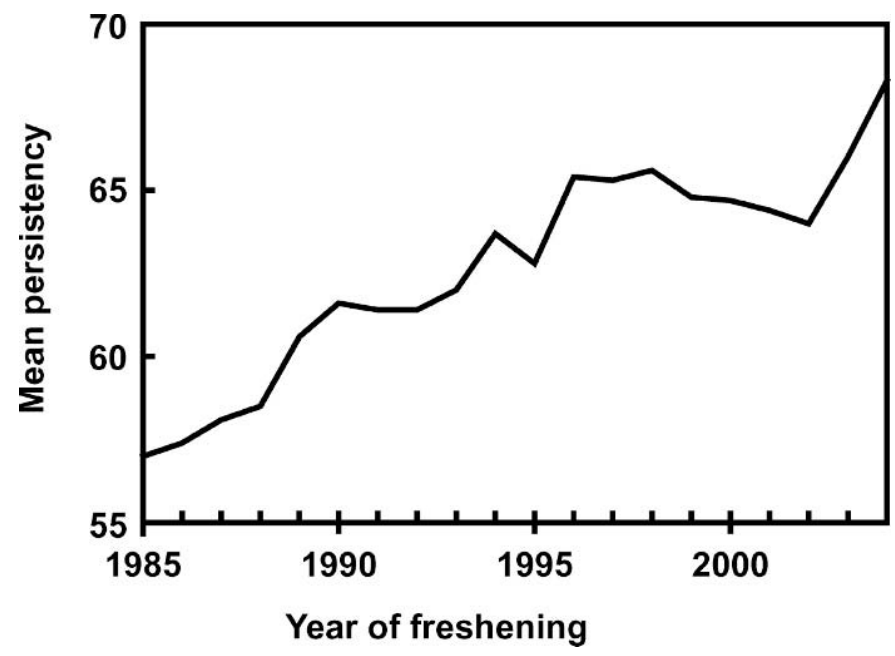

Figure 2. Mean adjusted persistency (in percent) by the cows' freshening year, including parities 1 through 5. were very similar to parity 3 , and therefore are not shown. As found by many previous studies, peak production was lower and later for first parity, but PER was higher (Weller et al., 1987; Gengler, 1996). Peak production increased, and PER decreased from second to third parity. Peak production was at $90 \mathrm{~d}$ for first parity and at approximately $45 \mathrm{~d}$ for later parities.

Effects of parity, DO, and freshening month by parity are given in Table 2. The quadratic effect of DO was not significant for either first or later parity, and therefore was deleted from the final analyses. All effects included in the final models were significant at $P<$ 0.005 by the type III sums of squares. As also can be seen in Figure 1, PER in second parity was $6 \%$ higher than in third parity, and continued to decrease through fourth parity. The values for third and fourth parity were negative relative to fifth parity, but the parity

Table 3. First- and second-parity means and standard deviations for persistency, milk production traits, SCS, female fertility, and herdlife records included in the REML2 and REML3 analyses

\begin{tabular}{lccccc}
\hline & \multicolumn{2}{c}{ First parity } & & \multicolumn{2}{c}{ Second parity } \\
\cline { 2 - 3 } \cline { 5 - 6 } Trait $^{1}$ & Mean & SD & & Mean & SD \\
\hline Persistency (\%) & 64.5 & 13.1 & 64.7 & 12.0 \\
Milk, kg & 10,881 & 1,520 & & 10,894 & 1,579 \\
Fat, kg & 354.9 & 54.5 & & 358.3 & 60.8 \\
Protein, kg & 329.8 & 43.1 & & 334.7 & 46.8 \\
SCS & 5.19 & 1.13 & & 4.88 & 1.22 \\
Fertility, \% & 53.3 & 34.2 & & 45.3 & 35.1 \\
Herdlife, ${ }^{2}$ d & 1,214 & 654 & & 1,424 & 596 \\
\hline Number of records & \multicolumn{3}{c}{89,046} & & \multicolumn{3}{c}{67,409} \\
\hline
\end{tabular}

${ }^{1}$ Milk production traits, SCS, and fertility were adjusted to fourthparity calvings in April. Persistency was adjusted to fifth-parity calvings in April.

${ }^{2}$ There was only a single herdlife record per cow. The difference in the means between first- and second-parity is because the secondparity sample includes only cows that produced second-parity records. 
Table 4. Genetic (above diagonal) and environmental (below diagonal) correlations and heritabilities (on the diagonal in bold type) by parity for persistency by the multitrait animal model in REML1 analysis $(62,510$ cows with records)

\begin{tabular}{llllll}
\hline & \multicolumn{5}{c}{ Parity } \\
\cline { 2 - 6 } Parity & 1 & 2 & 3 & 4 & 5 \\
\hline 1 & $\mathbf{0 . 1 6 4}$ & 0.854 & 0.783 & 0.771 & 0.709 \\
2 & 0.285 & $\mathbf{0 . 2 6 1}$ & 0.965 & 0.945 & 0.875 \\
3 & 0.240 & 0.438 & $\mathbf{0 . 2 6 9}$ & 0.996 & 0.964 \\
4 & 0.201 & 0.386 & 0.449 & $\mathbf{0 . 2 5 1}$ & 0.982 \\
5 & 0.151 & 0.294 & 0.364 & 0.384 & $\mathbf{0 . 1 7 6}$ \\
\hline
\end{tabular}

effects were computed relative to the base of zero DO. The effect of DO was negative for all parities other than fifth, and the effect of $\mathrm{DO}^{0.5}$ was positive for all parities, but lowest for fifth parity. Based on these regression coefficients, PER increased with increasing values of DO over the entire range of 0 to $200 \mathrm{DO}$ for all parities. Persistency was highest in June, July, and August for first, second, and later parities. Persistency was lowest for all parities 6 mo later, except for fourth. In Israel, cows suffer most from heat stress in the late summer months. Thus, peak production will be lowest for cows that reach peak production in August or September and highest for cows that reach peak production in the winter. Because peak production occurs earlier in laterparity cows, the months with highest and lowest PER were shifted accordingly. The difference between the months with the highest and lowest PER was $11 \%$ for first parity, but decreased with increasing parity. Mean adjusted PER by the cows' freshening year, including parities 1 through 5, are given in Figure 2. Mean PER increased from 57 to $68 \%$ over the last $20 \mathrm{yr}$.

First- and second-parity means and standard deviations for PER, milk production traits, SCS, and female fertility adjusted for DO, parity, and calving month, and herdlife are given in Table 3 . These values were similar to previous analyses of the Israeli Holstein population (Settar and Weller, 1999; Weller and Ezra, 2004). After adjustment for parity, means for first- and second-parity milk production traits were nearly equal.
As expected, mean PER of first and second parity were nearly equal after adjustment of all records to the base of fifth parity. The standard deviation of first parity was $11 \%$ greater than second parity.

Genetic and environmental correlations and heritabilities by parity for PER estimated with the multitrait animal model, REML1, are given in Table 4. Similar to previous studies (Gengler, 1996), environmental correlations among parities were all $<0.5$. However, similar to milk production traits, female fertility, and SCS, genetic correlations for PER between consecutive parities were all $>0.8$ (Weller and Ezra, 2004). The genetic correlation of 0.85 between first and second parity is somewhat surprising, considering the major difference in the shape of the lactation curve between first and second parities. Based on these values, a multiparity multitrait analysis is a reasonable alternative for routine genetic evaluation of PER.

These genetic correlations among parities in this study were higher than all previous estimates (Jamrozik et al., 1998; van der Linde et al., 2000; Gengler et al., 2001; de Roos et al., 2004), although all of these studies estimated PER differently. A possible reason for this difference may be that all previous studies assumed that peak production occurred at $60 \mathrm{DIM}$ for all parities, whereas in the current study peak production for heifers was assumed to occur at 90 DIM, which might have caused more re-ranking among parities in the previous studies.

Heritability increased from 0.16 to 0.27 from first through third parity, and then declined through fifth parity. These results are not in accordance with the results obtained on the same population for milk production traits, in which heritability decreased consistently with an increase in parity (Weller and Ezra, 2004). In both analyses the animals were a selected subset required to have completed five lactations. Cows with low PER or low production in the early lactations are more likely to be culled, and this should reduce both the phenotypic and genetic variances.

Genetic and environmental correlations and heritabilities for first-parity PER, milk production traits,

Table 5. Genetic (above diagonal) and environmental (below diagonal) correlations and heritabilities (on the diagonal in bold type) for first-parity persistency, milk production traits, SCS, female fertility, and herdlife by the multitrait animal model in REML2 analysis (89,046 cows with records)

\begin{tabular}{lcccccrc}
\hline & Persistency & Milk, kg & Fat, kg & Protein, kg & SCS & Fertility & Herdlife $^{1}$ \\
\hline Persistency & $\mathbf{0 . 1 7 4}$ & 0.074 & 0.009 & 0.018 & -0.045 & 0.199 & 0.254 \\
Milk, kg & 0.018 & $\mathbf{0 . 5 2 9}$ & 0.443 & 0.719 & 0.170 & -0.327 & 0.070 \\
Fat, kg & 0.011 & 0.556 & $\mathbf{0 . 4 8 5}$ & 0.579 & 0.095 & -0.257 & 0.146 \\
Protein, kg & 0.006 & 0.836 & 0.630 & $\mathbf{0 . 4 3 6}$ & 0.225 & -0.345 & 0.133 \\
SCS & -0.045 & 0.007 & -0.009 & 0.041 & $\mathbf{0 . 2 4 9}$ & -0.287 & -0.358 \\
Fertility & 0.001 & -0.021 & -0.038 & -0.030 & -0.034 & $\mathbf{0 . 0 2 8}$ & 0.535 \\
Herdlife & 0.069 & 0.067 & 0.069 & 0.074 & -0.115 & 0.135 & $\mathbf{0 . 1 0 2}$ \\
\hline
\end{tabular}

${ }^{1}$ There was a single herdlife record per cow; all the other traits are for first parity. 
Table 6. Genetic (above diagonal) and environmental (below diagonal) correlations and heritabilities (on the diagonal in bold type) for second-parity persistency, milk production traits, SCS, female fertility, and herdlife by the multitrait animal model in REML3 analysis (67,409 cows with records)

\begin{tabular}{lccrcrrr}
\hline Traits & Persistency & Milk, kg & Fat, kg & Protein, kg & \multicolumn{1}{c}{ SCS } & Fertility & Herdlife $^{1}$ \\
\hline Persistency & $\mathbf{0 . 2 5 3}$ & 0.425 & 0.340 & 0.426 & -0.136 & 0.102 & 0.582 \\
Milk, kg & 0.219 & $\mathbf{0 . 3 5 9}$ & 0.275 & 0.666 & 0.128 & -0.194 & 0.260 \\
Fat, kg & 0.194 & 0.555 & $\mathbf{0 . 3 5 4}$ & 0.448 & -0.107 & -0.131 & 0.341 \\
Protein, kg & 0.233 & 0.843 & 0.634 & $\mathbf{0 . 3 1 6}$ & 0.049 & -0.303 & 0.367 \\
SCS & -0.106 & -0.100 & -0.128 & -0.079 & $\mathbf{0 . 2 0 3}$ & -0.236 & -0.487 \\
Fertility & 0.092 & 0.033 & 0.012 & 0.019 & -0.048 & $\mathbf{0 . 0 4 0}$ & 0.467 \\
Herdlife, d & 0.202 & 0.162 & 0.144 & 0.168 & -0.192 & 0.213 & $\mathbf{0 . 0 9 9}$ \\
\hline
\end{tabular}

${ }^{1}$ There was a single herdlife record per cow; all the other traits are for second parity.

SCS, female fertility, and herdlife by the multitrait animal model are given in Table 5. Heritability for PER in this analysis, denoted REML2, was 0.17 , as compared with 0.16 in REML1, even though the REML2 analysis required valid records only for first parity. Therefore, the cows included in REML2 were a less stringently selected sample. However, the REML2 sample was still selected, because cows were required to have valid records for all 7 traits, and only cows that were inseminated at least once had fertility records. Genetic correlations among milk production traits, fertility, and SCS were similar to many previous analyses (e.g., Weller and Ezra, 1997). Genetic correlations with PER were all $<0.1$, except for fertility and herdlife, which were 0.2 and 0.25 , respectively. The correlation between PER and fertility was less than the value of 0.3 found by Muir et al. (2004). However, both fertility and PER were defined somewhat differently. The absolute value of the genetic correlation between PER and herdlife was slightly less than the genetic correlation between herdlife and SCS. The heritability values for the milk production traits were higher than those presented by Weller and Ezra (2004), who found a heritability of 0.39 for first-parity milk production. However, the population samples were different, and Weller and Ezra (2004) included only cows with valid records for all 5 parities. Because milk production traits are the major criterion for culling cows, it is reasonable that first- and second-parity heritabilities would be lower for cows with 5 parities, as compared with an "unselected" sample of cows.

Genetic and environmental correlations and heritabilities for second-parity PER, milk production traits, SCS, female fertility, and herdlife estimated with the multitrait animal REML3 are given in Table 6. Again, the heritability for PER was very close to the value in the REML1 analysis, despite the fact that the REML1 analysis was based on a more selected sample of cows. The genetic correlations with PER were unexpectedly quite different from the first-parity values, considering the high genetic correlation of 0.85 between first- and second-parity PER. Second-parity genetic correlations of PER with the 3 milk production traits were all $>0.3$, whereas the genetic correlation with fertility was only 0.1 . The genetic correlation with herdlife was 0.58 . No other values from the literature were available for comparison. All genetic correlations were economically favorable, including SCS, assuming that increasing milk yield and decreasing SCS are economically desirable. Similar to the results of Weller and Ezra (2004), heritability for milk production traits decreased from first to second parity. Heritability for milk in REML3 was higher than second-parity heritability reported by Weller and Ezra (2004). Second-parity heritabilities for the

Table 7. Genetic (above diagonal) and environmental (below diagonal) correlations and heritabilities (on the diagonal in bold type) for first- and second-parity persistency, milk production traits, female fertility, and herdlife by the multitrait animal model in REML4 analysis (68,777 cows with records)

\begin{tabular}{|c|c|c|c|c|c|c|c|c|}
\hline \multirow[b]{2}{*}{ Trait } & \multirow[b]{2}{*}{ Parity } & \multicolumn{2}{|c|}{ Persistency } & \multicolumn{2}{|c|}{ Milk } & \multicolumn{2}{|c|}{ Fertility } & \multirow[b]{2}{*}{ Herdlife $^{1}$} \\
\hline & & Parity 1 & Parity 2 & Parity 1 & Parity 2 & Parity 1 & Parity 2 & \\
\hline \multirow{2}{*}{ Persistency } & 1 & 0.173 & 0.793 & 0.142 & 0.227 & 0.253 & 0.138 & 0.350 \\
\hline & 2 & 0.270 & 0.251 & 0.238 & 0.390 & 0.083 & 0.113 & 0.569 \\
\hline \multirow[t]{2}{*}{ Milk } & 1 & 0.012 & 0.117 & 0.504 & 0.912 & -0.312 & -0.291 & 0.042 \\
\hline & 2 & 0.122 & 0.210 & 0.609 & 0.378 & -0.247 & -0.202 & 0.231 \\
\hline \multirow[t]{2}{*}{ Fertility } & 1 & 0.004 & 0.040 & 0.003 & -0.039 & 0.026 & 0.690 & 0.238 \\
\hline & 2 & 0.007 & 0.096 & -0.035 & 0.043 & 0.081 & 0.040 & 0.577 \\
\hline Herdlife & & 0.064 & 0.201 & 0.051 & 0.150 & -0.001 & 0.218 & 0.091 \\
\hline
\end{tabular}

${ }^{1}$ There was a single herdlife record per cow. 
Table 8. Correlations among sire evaluations for persistency, milk production traits, SCS, female fertility, and herdlife (927 bulls with reliability for persistency $>0.75$ )

\begin{tabular}{|c|c|c|c|c|c|c|}
\hline & Milk, kg & Fat, kg & Protein, $\mathrm{kg}$ & SCS & Fertility & Herdlife \\
\hline Persistency & 0.372 & 0.226 & 0.305 & -0.075 & 0.130 & 0.409 \\
\hline Milk, kg & - & 0.472 & 0.716 & 0.111 & -0.095 & 0.612 \\
\hline Fat, kg & - & - & 0.745 & -0.056 & -0.137 & 0.458 \\
\hline Protein, kg & - & - & - & 0.052 & -0.190 & 0.585 \\
\hline SCS & - & - & - & - & -0.212 & -0.265 \\
\hline Fertility & - & - & - & - & - & 0.317 \\
\hline
\end{tabular}

other traits were very similar to the results of Weller and Ezra (2004).

To further investigate these discrepancies, an additional REML analysis, REML4, was computed, which included the first- and second-parity records for PER, milk yield, and the nonproduction traits that showed the greatest changes in genetic correlations between first and second parities; namely, female fertility and herdlife. Results from REML4 analysis (Table 7) were quite similar to results from REML2 or REML3 analyses. The correlation between first- and second-parity PER, 0.79, was slightly lower than the corresponding value in the REML1 analysis. The first-parity genetic correlation between PER and milk was lower than the corresponding second-parity correlation, whereas the first-parity correlation between PER and fertility was higher than the corresponding second-parity correlation. Surprisingly, the correlation between first-parity PER and milk was lower than the correlations between first-parity PER and second-parity milk, and secondparity PER and first-parity milk yield.

Correlation among sire evaluations for PER, milk production traits, SCS, female fertility, and herdlife are given in Table 8 for bulls with reliabilities $>0.75$ for PER. The correlations with PER correspond closely to the REML3 genetic correlations (Table 6), but not to the REML2 correlations (Table 5), even though some of the younger bulls had daughters with only first-parity records. Thus, it is likely that later parity genetic correlations were similar to the second-parity correlations.

Correlations among sire evaluations also included the effect of genetic trends over time. Therefore, correlations between the genetic evaluations among the milk production traits and between these traits and herdlife were higher than the genetic correlations because the correlations among the genetic evaluations also included the effect of the genetic trends, which were positive for both the milk production traits and herdlife.

Genetic and phenotypic trends for PER by parity and for the multiparity index BVT are given in Table 9. All trends were positive, and the later-parity genetic trends were $>50 \%$ of the phenotypic trends. Thus, a fraction of the increase in PER was due to nongenetic factors, especially in first parity. Increase in the multiparity index was $0.22 \% / y r$, even though there was no direct selection on PER. This is not surprising considering 1) the positive genetic correlations between second-parity PER and all the traits included in the Israeli selection index, and 2) the positive genetic correlations between the sire genetic evaluations for PER and the selection index traits. The mean phenotypic trend of $0.44 \% / \mathrm{yr}$ corresponded to a gain of $9 \%$ in $20 \mathrm{yr}$, which was slightly less than the difference of $11 \%$ in Figure 2 between the 2 time points 20 -yr distant. These results clearly indicate that selection for PER has occurred in the Israeli Holstein population via correlations with the index traits. Average first-parity PER and average cow breeding values for PER by birth year are given in Figure 3. The difference in the phenotypic annual means between Figures 2 and 3 is because Figure 2 was based on all 5 parities, whereas Figure 3 was based only on first-parity PER.

\section{CONCLUSIONS}

In the multiparity analysis, heritability of PER increased from 0.16 to 0.27 from first through third parity, and then declined through fifth parity. Genetic correlations for PER between consecutive parities were all $>0.8$. First-parity genetic correlations of the traits included in the Israeli selection index with PER were all $<0.1$, except for fertility and herdlife, which were 0.2 and 0.25 , respectively; second-parity genetic correla-

Table 9. Genetic and phenotypic trends for persistency by parity

\begin{tabular}{lllll}
\hline & & \multicolumn{3}{c}{ Trends (\%/yr) } \\
\cline { 3 - 5 } Parity & $\begin{array}{l}\text { No. of } \\
\text { records }\end{array}$ & Phenotypic & Genetic & $\begin{array}{l}\text { Genetic/ } \\
\text { phenotypic }\end{array}$ \\
\hline 1 & 484,721 & 0.44 & 0.15 & 0.34 \\
2 & 340,635 & 0.47 & 0.25 & 0.53 \\
3 & 211,973 & 0.48 & 0.26 & 0.54 \\
4 & 120,957 & 0.43 & 0.25 & 0.58 \\
5 & 62,510 & 0.38 & 0.23 & 0.61 \\
Index $^{2}$ & 577,305 & & 0.22 &
\end{tabular}

${ }^{1}$ No. of records for the individual parities refers to the phenotypic trends. The genetic trends were based on all 577,305 cows with evaluations.

${ }^{2}$ Calculation of the multiparity index is given in the text. 


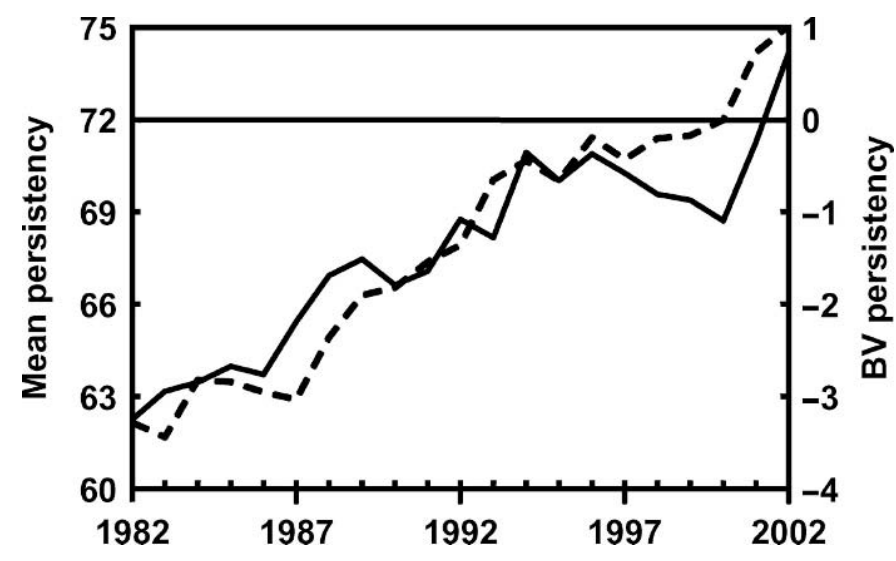

Figure 3. Mean first-parity persistency (in percent; solid curve) and mean breeding values for persistency (BV persistency; in percent relative to the genetic base; dashed curve) by birth year. The horizontal line denotes the genetic base for the animal model analysis.

tions of PER with the 3 milk production traits were all $>0.3$, and the genetic correlation with fertility was only 0.1 . The genetic correlation between second-parity PER and herdlife was 0.58 . Increase in the multiparity index was $0.22 \% / y r$, even though there was no direct selection on PER.

\section{ACKNOWLEDGMENTS}

This research was supported by a grant from the Israel Milk Marketing Board. We thank I. Misztal for use of the MTC REML program.

\section{REFERENCES}

Bar-Anan, R. M., and G. R. Wiggans. 1985. Associations among milk yield, yield persistency, conception and culling of Israeli Holstein dairy cattle. J. Dairy Sci. 68:382-386.

Da, Y., and M. Grossman. 1991. Multitrait animal-model with genetic groups. J. Dairy Sci. 74:3183-3195.

Dekkers, J. C. M., J. H. ten Haag, and A. Weersink. 1998. Economic aspects of persistency of lactation in dairy cattle. Livest. Prod. Sci. 53:237-252.

de Roos, A. P. W., A. G. F. Garbers, and G. de Jong. 2004. Random herd curves in a test-day model for milk, fat, and protein production of diary cattle in the Netherlands. J. Dairy Sci. 87:2693-2701.

Ezra, E., and J. I. Weller. 2005. The December 2004 genetic evaluation. Meshek Habakar Vehahalav 314:16-17. [in Hebrew]

Ezra, E., J. I. Weller, and D. Drori. 1987. Estimation of environmental effect on milk protein content. Heker Umas 9:31-35. [In Hebrew]

Ferris, T. A., I. L. Mao, and C. R. Anderson. 1985. Selecting for lactation curve and milk yield in dairy cattle. J. Dairy Sci. 68:1438-1448.
Gengler, N. 1996. Persistency of lactation yields: A review. Proc. Int. Workshop on Genetic Improvement of Functional Traits in Cattle, Gembloux, Belgium. Interbull Bull. 12:87-96.

Gengler, N., A. Tijani, G. R. Wiggans, and J. C. Philpot. 2001. Estimation of (co)variance functions for test-day yields during first and second lactations in the United States. J. Dairy Sci. 84 (Feb.). Online. Available: http://jds.fass.org/content/vol84/issue2/

Grossman, M., A. L. Kuck, and H. W. Norton. 1986. Lactation curves of purebred and crossbred dairy cattle. J. Dairy Sci. 69:195-203.

Jakobsen, J. H., R. Rekaya, J. Jensen, D. A. Sorensen, P. Madsen, D. Gialona, L. G. Christensen, and J. Pedersen. 2003. Bayesian estimates of covariance components between lactation curve parameters and disease liability in Danish Holstein cows. J. Dairy Sci. 86:3000-3007.

Jamrozik, J., G. Jansen, L. R. Schaeffer, and Z. Liu. 1998. Analysis of persistency of lactation calculated from a random regression test day model. Proc. Interbull Mtg. Rotorua, New Zealand. Interbull Bull. 17:64-67.

Kistemaker, G. J. 2003. Comparison of persistency definitions in random regression test day models. Proc. Interbull Technical Workshop. Beltsville, MD. Interbull Bull. 30:96-98.

Misztal, I., T. J. Lawlor, T. H. Short, and G. R. Wiggans. 1991. Continuous genetic evaluation of Holstein for type. J. Dairy Sci. 74:2001-2009.

Misztal, I., and G. R. Wiggans. 1988. Approximation of prediction error variance in large-scale animal models. J. Dairy Sci. 71(Suppl. 2):27-32.

Muir, B. L., J. Fatehi, and L. R. Schaeffer. 2004. Genetic relationships between persistency and reproductive performance in first-lactation Canadian Holsteins. J. Dairy Sci. 87:3029-3037.

Settar, P., and J. I. Weller. 1999. Genetic analysis of cow survival in the Israeli dairy cattle population. J. Dairy Sci. 82:2170-2177.

Solkner, J., and W. Fuchs. 1987. A comparison of different measures of persistency with special respect to variation of test-day milk yields. Livest. Prod. Sci. 16:305-319.

Swalve, H. H., and N. Gengler. 1999. Genetics of lactation persistency. Occ. Publ. Br. Soc. Anim. Sci. 24:75-82.

Togashi, K., and C. Y. Lin. 2003. Modifying the lactation curve to improve lactation milk and persistency. J. Dairy Sci. 86:14871493.

Togashi, K., and C. Y. Lin. 2004a. Development of an optimal index to improve lactation yield and persistency with the least selection intensity. J. Dairy Sci. 87:3047-3052.

Togashi, K., and C. Y. Lin. 2004b. Efficiency of different selection criteria for persistency and lactation milk yield. J. Dairy Sci. 87:1528-1535.

van der Linde, R., A. Groen, and G. de Jong. 2000. Estimation of genetic parameters for persistency of milk production in dairy cattle. Proc. Interbull Mtg. Bled, Slovenia. Interbull Bull. $25: 113-116$

Weller, J. I., and E. Ezra. 1997. Genetic analysis of somatic cell concentration and female fertility of Israeli Holsteins by the individual animal model. J. Dairy Sci. 80:586-593.

Weller, J. I., and E. Ezra. 2004. Genetic analysis of the Israeli Holstein dairy cattle population for production and non-production traits with a multitrait animal model. J. Dairy Sci. 87:1519-1527.

Weller, J. I., M. Ron, and R. Bar-Anan. 1987. Effects of persistency and production on the genetic parameters of milk and fat yield in Israeli-Holsteins. J. Dairy Sci. 70:672-680.

Wilmink, J. B. M. 1987. Adjustment of test-day milk, fat and protein yield for age, season and stage of lactation. Livest. Prod. Sci. 16:335-348.

Zimmermann, E., and H. Sommer. 1973. Zum Laktationsverlauf von Kuhen in Hochleistung-sherden und dessen Beeinflussung durch nichterbliche Faktoren. Zuchtungskunde 45:75-88. 